\title{
The tranquil consciousness of effortless superiority
}

\author{
Alden H. Harken, MD, FACS
}

\author{
From the Department of Surgery, University of California, San Francisco-East Bay, Oakland, Calif. \\ Disclosures: Author has nothing to disclose with regard to commercial support. \\ Received for publication July 3, 2018; revisions received July 3, 2018; accepted for publication July 6, 2018; \\ available ahead of print Aug 31, 2018. \\ Address for reprints: Alden H. Harken, MD, FACS, Department of Surgery University of California, San \\ Francisco-East Bay, 1411 E 31st St (QIC 22134), Oakland, CA 94602 (E-mail: alden.harken68@gmail.com). \\ J Thorac Cardiovasc Surg 2019;157:231 \\ $0022-5223 / \$ 36.00$ \\ Copyright (c) 2018 by The American Association for Thoracic Surgery \\ https://doi.org/10.1016/j.jtcvs.2018.07.004
}

During the mid-1980s, we all knew that sinus rhythm originated in the S-A node, atrial flutter was a re-entrant rhythm, and atrial fibrillation was inscrutable chaos. Then, in 1988, Jimmy Cox and Jack Boineau placed 156 atrial epicardial bipolar electrodes in 14 patients during WPW surgery. ${ }^{1}$ That study demonstrated that atrial activation maps could be meaningfully produced clinically, and that there were many widely divergent extranodal atrial pacemaker sites. The right atrial pacemaker region extended from the sulcus terminalis posterior and up to the precaval band anteriorly, but left atrial escape pacemakers were also clearly documented. At that point, most of us were confident that atrial fibrillation derived from a million atrial cardiomyocytes firing spontaneously, chaotically, and completely independently.

The conceptual breakthrough came when the Cox-Boineau team conceived of atrial fibrillation as a re-entrant rhythm. Then, in a 1991 series of 4 publications, ${ }^{2-5}$ they reported testing surgical strategies of isolating the re-entrant circuitry in dogs. If atrial fibrillation was just a bunch of irritable myocytes firing independently, then a group of surgical incisions might make things even worse. However, if atrial fibrillation really was re-entrant, a surgical incision might serve as an effective barrier to conduction of the re-entrant impulse. I remember thinking, at a National Institutes of Health study section, that there was no way it could work. Cox and Boineau ${ }^{2}$ began their breakthrough article with: "On the basis of known electrophysiologic mechanisms of atrial fibrillation..." For me (and I think for most of us) there were no known mechanisms of atrial fibrillation. But with the tranquil consciousness of effortless superiority, the authors forged ahead and created a surgical therapy for the very common and debilitating problem of atrial fibrillation.

In a patient with atrial fibrillation and a large left atrium secondary to mitral valve disease, a formal Cox-maze IV biatrial procedure takes a little longer. But it is doable. In a deep-chested man with atrial fibrillation and small-tonormal sized atria, the biatrial procedure can be a struggle, so a compromise procedure was really appealing. With been proposed.

\section{References}

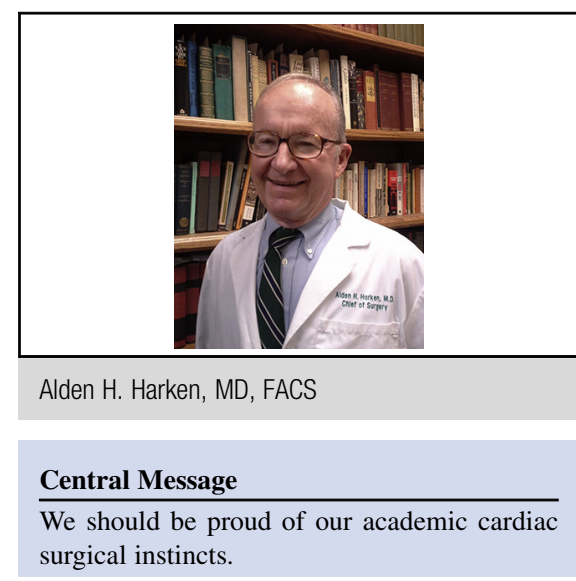

See Article page 234.

years of experience, it is now apparent that the zone surrounding the pulmonary veins is disproportionately the dysrhythmia culprit. Half-Cox-maze pulmonary vein isolation procedures - both intra- and extracardiac-have

In a beautiful example of everything that is good about academic cardiac surgery, Blackstone and colleagues 6 prospectively randomized 260 patients with chronic atrial fibrillation to mitral valve surgery plus or minus biatrial Cox-maze or pulmonary vein isolation. All 3 approaches provided gratifyingly successful results. Looking back at the original data from Cox and Boineau, in which the right atrium was occasionally the culprit, it is predictable that inclusion of the right atrium in the formal isolation is, indeed, a little better.

1. Boineau JP, Canavan TE, Schuessler RB, Cain ME, Corr PB, Cox JL. Demonstration of a widely distributed atrial pacemaker complex in the human heart. Circulation. 1988;77:1221-37.

2. Cox JL, Schuessler RB, D'Agostino HJ Jr, Stone CM, Chang BC, Cain ME, et al The surgical treatment of atrial fibrillation. III. Development of a definitive surgical procedure. J Thorac Cardiovasc Surg. 1991;101:569-83.

3. Yagi Y, Schuessler RB, Boineau JP, Cox JL. Feasibility of closed heart discrete cryomodification of atrioventricular conduction. Electrophysiologic effects in the canine heart. J Thorac Cardiovasc Surg. 1991;101:1004-15.

4. Cox JL, Boineau JP, Schuessler RB, Ferguson TB Jr, Cain ME, Lindsay BD, et al Operations for atrial fibrillation. Clin Cardiol. 1991;14:827-34.

5. Cox JL, Boineau JP, Schuessler RB, Ferguson TB Jr, Cain ME, Lindsay BD, et al Successful surgical treatment of atrial fibrillation. Review and clinical update. JAMA. 1991;266:1976-80.

6. Blackstone EH, Chang HL, Rajeswaran J, Parides MK, Ishwaran H, Li L, et al Biatrial maze procedure versus pulmonary vein isolation for atrial fibrillation during mitral valve surgery: new analytical approaches and end points. J Thorac Cardiovasc Surg. 2019;157:234-43.e9. 